\title{
Theoretical/Historical Account of Public Opinion Survey and Its Importance
}

\author{
Medani P. Bhandari
}

$\mathrm{PhD}$, Professor and Deputy Program Director of Sustainability Studies, Akamai University, Hawaii, USA; Professor of Economics and Entrepreneurship, Sumy State University, Ukraine

"Truth reveals itself in degrees, and we can progress from an incomplete to a more and ever more complete comprehension of truth. Truth is not a thing, not an object that we either have in entirety or have not at all". - Johann Wolfgang von Goethe (1749-1832).

Opinion polls and opinion surveys include all systematic gathering, aggregating and interpretation of information about policy, electoral and other preferences and behaviors of individuals or organizations using the statistical and analytical methods and techniques of the applied social sciences in order to gain insight and support decision-making. In opinion research, as in all market research, the identity of respondents will not be revealed without explicit consent and no sales approach, or attempt to influence their opinion following the interview, will be made to respondents as a direct result of their having provided information (Esomar and Wapor 2014).

\begin{abstract}
This paper illustrates the theoretical and historical account of public opinion survey with reference to public policy (any field-infrastructure, development, environment management, etc.). Paper is based on secondary information and provides a general base of the public opinion survey. The purpose of the paper is to outline the foundation of public opinion collection and use in the policy formulation on general public concern issues such as climate change. This paper summarizes the arguments and counterarguments within the scientific discussion on the issue Theoretical/Historical Account of Public Opinion Survey and Its Importance. The main purpose of this paper is to give a general sense of what is public opinion, what is its origin and use. This short paper illustrates literary sources and approaches on public opinion survey mostly created for solving the social problem. Investigation of the topic shows that the importance of public opinion cannot be avoided in the contemporary world, however the ways of collecting opinions may vary. Methodologically, this paper is completely based on secondary data, literature survey methods. Primarily this paper is based on authors teaching material and epistemology of public opinion survey and polls. The core objective of this research is to make students and researcher familiar about the public opinion, so the paper does not follow the research format trajectory. The results of the research can be useful for students, researchers and policymakers who often used public opinion survey to make decision or policy.
\end{abstract}

Keywords: public opinion, historical account, theory, intellectual, debate, definition.

JEL Classification: Z13, Z18.

Cite as: Bhandari, M.P. (2019). Theoretical/Historical Account of Public Opinion Survey and Its Importance. Business Ethics and Leadership, 3(1), 101-108. http://doi.org/10.21272/bel.3(1).101-108.2019.

(C) The Author, 2019. This article is published with open access at Sumy State University.

\section{Introduction}

The concept of public opinion survey can be traced as early as the time of Plato \& Aristotle -4 th Century BC, whereas Plato distrusted the masses because of the uncertainty of the public understanding of intellectual debates. However, Aristotle believed in the power of the community and argued to consider the norms, values, and interest of the citizens during the formation of the government's policies. There was a long gap of philosophical debate from the $1^{\text {st }}$ century to the $16^{\text {th }}$ century on the issue of public concern because the rulers enjoyed a supreme power and ruled the world with the distinct division of rulers and ruled. In the $16^{\text {th }}$ century Machiavelli challenged the notion of rulers and ruled and acknowledged that public opinion has the political force and the rulers must incorporate the public voice because the society holds the dialectic values between the rulers and ruled (Gilbert, 1938; Schaefer, 1990; Mansfield, 1995). This theoretical frame further fostered during the $17^{\text {th }}$ century, when contrast theorists Hobbes and Locke argued that the formation of the state public participation is important, and state creates the contract between rulers and the citizens and established the notion that public the opinion should consider as the expression of the democratic rights of the citizens (Strauss, 
ISSN (online) - 2520-6311; ISSN (print) - 2520-6761

1936; Aaron, 1937; Macpherson, 1962; Colman, 1983; Skinner, 1996; Tuckness, 2010). This notion further theorized during the $18^{\text {th }}$ century, particularly with the contribution of Rousseau, who extensively argued for the empowerment of the citizens; respect the communities' views and interests of the general public (Cassirer, 1945; LaFreniere, 1990; Bhandari, 2000; Damrosch, 2005). The 19 $19^{\text {th }}$ century, which is also known as the era of the knowledge, actually established public opinion as an academic field of study and formalized the frame of the public opinion survey. The major contributors on public opinions of the $19^{\text {th }}$ century include Bentham, who argued public opinion as a sanction, a force to keep society in equilibrium and creator of normative behaviors in the society (Rosen, 1983; Dinwiddy, 1989; Robinson and Groves, 2003). Similarly Mills highlighted on the majority of the opinions, i.e. largest the opinions better the outcome (Duncan, 1973; Crisp, 1997; Bromwich and Kateb, 2003); Tocqueville took Public opinion as a force of social control (Pierson, 1938; Cheryl, 2006; Zunz, 2011) and Marx provided a contrasting view stating that Common citizens tend to mimic the opinions of the ruling class - people with wealth and power and hegemony controls the mass consciousness respectively (Avineri, 1968; McLellan, 2007; Callinicos, 2010).

The $20^{\text {th }}$ century is considered as conflict era of the power dynamics which faced the greatest wars as well as created the institution for the peace (i.e. United Nation). During this era, the norms for the democracy were further strengthened where, public opinion (votes, expressions, media, and participation in the survey system) has been the major tool in understanding the societal situation in any field related to human wellbeing. Theorist such as Bryce (Bryce, 1921; Keller, 1988; Wright, 2001) and Tarde focused the media houses as an advocate of the public opinions for the democratization process (Kinnunen, 1996; Toews, 2003; Latour, 2005).

It is a known fact that the survey on public opinions has a long history particularly in the discipline of political science. As noted by W. Phillips Davison in 1958, there has been a long legacy in understanding the public opinion in various disciplines. Davison cites to Wieland (German Poet):

I, for my part, understand by it an opinion that gradually takes root among a whole people; especially among those who have the most influence when they work together as a group. In this way, it wins the upper hand to such an extent that one meets it everywhere. It is an opinion that without being noticed takes possession of most heads and even in situations where it does not dare to express itself out loud it can be recognized by a louder and louder muffled murmur. It then only requires some small opening that will allow it air, and it will break out with force. Then it can change whole nations in a brief time and give whole parts of the world a new configuration (Wieland in Gesprach unter vier Augen 1798 as in Davison, 1958: 91).

Davison (1958: 91) summarizes that the authors, prior to 1900, usually agree on two aspects (public opinion's): that it is a consensus among a large number of people, and that this consensus somehow exercises force. On the basis of this classical frame and on the basis of Allport, Floyd H. (1937) writings, Davison, summarizes:

Public opinion is the result of psychological and social processes that lead to a situation in which the behavior of each member of public in regard to an issue is conditioned by his expectation that other members of the public hold similar attitudes on the same issue. The public opinion process involves the formation of individual attitudes and opinions, group opinion processes, "personal sampling", and inter-group communication Opinion Process (Davison, 1958: 91).

Speier, Hans (1950: 376) also took public opinion as a process of communication, such as:

Public opinion, defined for purposes of this historical review as free and public communication from citizens to their government on matters of concern to the nation, is a phenomenon of middle-class civilization. Its attainment of political significance was accompanied and facilitated by certain changes in the economic and convivial institutions of society and by shifts in social stratification. In its early phase public opinion was preoccupied with domestic affairs, but during the French Revolutionary wars and after the Congress of Vienna the utilization of public opinion in international affairs became generally respectable among statesmen. Effective government by public opinion in the field of foreign affairs today is jeopardized by various specified characteristics of modern democratic civilization.

Throughout the public opinion scholarships, there are verities of definitions of the public opinions. The World Bank's Communication for Governance and Accountability Program (CommGAP), has nicely summarized the definitions of the public opinions in two major frames, such as Traditional and Modern. 
Table 1. Definitions of public opinion traditional/modern

\begin{tabular}{|c|c|}
\hline Traditional definitions of the public opinions & Modern definitions of the public opinions \\
\hline $\begin{array}{l}\text { Traditional senses of "the public" include } \\
\text { beliefs, attitudes, and opinions about the } \\
\text { following: } \\
\text { - Affairs related to the state, the government, or } \\
\text { broad social institutions. } \\
\text { - Something that is open and accessible to } \\
\text { everyone. } \\
\text { - All the people who are affected by an event, } \\
\text { policy, or decision. While "private" actions } \\
\text { concern only those who participate in them, } \\
\text { "public" actions affect both participants and the } \\
\text { rest of the people either directly or indirectly.1 } \\
\text { - Something that is of common concern. } \\
\text { - The public good, as opposed to the private } \\
\text { interests of individuals who represent only a } \\
\text { segment of the broader public. }\end{array}$ & $\begin{array}{l}\text { The modern sense of public opinion is multidimensional and has the following } \\
\text { characteristics: } \\
\text { - It represents only one prevailing opinion among many possible ones. } \\
\text { - It tends to be transitory. } \\
\text { - It refers to the opinion that seems to be the most dominant, widespread, or } \\
\text { popular, even though there will always be a plurality of existing public } \\
\text { opinions. } \\
\text { - It relates to "action or readiness for action with regard to a given issue on the } \\
\text { part of members of a public who are reacting in the expectation that others in } \\
\text { the public are similarly oriented toward the same issue." } \\
\text { - It is jointly produced by the following: (a) elite opinion leaders who express } \\
\text { and publish opinions, } \\
\text { have access to media outlets and technologies and have high degrees of social } \\
\text { influence or institutional power; (b) statistical records, which represent and } \\
\text { measure opinions collected through polls and surveys; and (c) people's "quasi- } \\
\text { statistical sense" of which opinions prevail in their social and media } \\
\text { environments, as well as how their own opinions match up with others'. }\end{array}$ \\
\hline \multicolumn{2}{|c|}{$\begin{array}{l}\text { Dimensions of Opinion can be seen on the basis of } \\
\text { - Cognitive/Theoretical: Beliefs about the objective truth of factual, historical, or scientific matters. } \\
\text { - Normative/Practical: Beliefs about the moral or ethical rightness of actions, decisions, policies, practices, norms, laws, or } \\
\text { values. } \\
\text { - Expressive/Evaluative: Beliefs about the truthfulness or sincerity of people's subjective expressions of who they are and what } \\
\text { they believe. Also, beliefs about the authenticity of expressions - i.e., whether an utterance or a cultural work (e.g., a work of art, } \\
\text { a literary text, or a film) adequately express a personal viewpoint, a tradition, a coherent worldview, an artistic vision, or a group } \\
\text { identity. }\end{array}$} \\
\hline
\end{tabular}

Source: World Bank-CommGAP (2008: 1-2)

Traditional definition summary is produced on the basis of Mill (1863); Dewey (1988); and Modern definitions are drawn from Davison (1958) and Allport (1937) and other i.e. Blumer (1969); Habermas (1984); Beniger (1992); Splichal (1999) respectively as in the World Bank-CommGAP (2008: 1-2).

As shown in the Table, the collection of public opinion is a complex phenomenon and there is no uniformity in the methods as well as in practice. The practice of opinion survey can be seen in various aspects of society, mostly to make the decision for public welfares. The purpose of public opinion survey depends on what, surveyors want to know, what method they have used and how they want to utilize acquired information. There is always a question, whether collected opinions represents the truth?

Mostly, the public opinion surveyors use the representative samples and draw the conclusion. In this process, it is hard to know the fact that, the responses, represent the rest of the population who were not participants of the survey. Even there are no ways to guaranty, that opinions are free from biases. Whatever is the case the importance of public opinion survey cannot be replaced. Why are opinion polls important? As Gallup (2012), states, opinion survey helps to general people to be heard in the decision-making system. "Polls tell us what proportion of a population has a specific viewpoint. They do not explain why respondents believe as they do or how to change their minds. This is the work of social scientists and scholars. Polls are simply a measurement tool that tells us how a population thinks and feels about any given topic. This can be useful in helping different cultures understand one another because it gives the people a chance to speak for themselves instead of letting only vocal media stars speak on behalf of all. Opinion polling gives people who do not usually have access to the media an opportunity to be heard" (Gallup, 2012).

Following the classical approaches (to know the public concern on the important problem), the contemporary scholars largely used from the secondary data from the various sources (including individual scholars, polling agencies, library, news, websites etc.). More importantly, in contemporary society, there are professional agencies who conduct surveys. Such agencies include the Gallup Organization, Roper Organization, Cambridge Reports, Inc, Louis Harris and Associates, National Broadcasting Company, World Public Opinion Organization, The World Bank, International Development Research Centre, The Pew Global Attitudes Project, GlobeScan etc. In addition to these major opinion survey agencies, some individuals/scholars also collect own data to investigate the public opinions on global issues, using various survey techniques/methods.

In terms of methodology, throughout the survey history, public opinion surveys have been utilizing the formal (quantitative and qualitative approaches) and informal tools (elections; interest groups and lobbying; the media; letters and calls; protests; straw polls). The major public opinion survey agencies utilize the formal 
ISSN (online) - 2520-6311; ISSN (print) - 2520-6761

approach. The public opinion surveys follow the notion of three public opinion dimensions - i.e., cognitive/theoretical matters of truth, or normative/practical matters of rightness, or expressive/evaluative matters of sincerity and authenticity embedded on the specific issues of public concern (World BankCommGAP, 2008). By principle, as World Bank- CommGAP (2008) notes the opinions are expressed through the communication channels and opinions are formed through the combinations and interactions of interpersonal and mass-mediated communication. Broadly, the opinions survey intends to capture the notion of the perceptions of reality, which comes through the people's perceptions of "what the case is" in the material world, in the social world, and in themselves, as well as their judgments about how those three dimensions of reality intersect with the Demographic, Social, and Psychological Characteristics. These characteristics are potentially relevant to public opinion research, including the following: race, class, gender, age, educational level, cultural tastes, group affiliations, access to information, media use, social position, occupation, opinion leadership, fear of isolation, conformity, etc. (World Bank- CommGAP, 2008: 3). However, there is no certainty that public opinion captures the Perceptions of Reality. There could be various influences of perception on public opinion, such as pluralistic ignorance; looking glass perception; the spiral of silence (SOS) theory; third-person effect; false consensus; conservative bias etc. (Ross and House, 1977; Millera and McFarland, 1987; Shamir, 1993).

Whereas, according to Millera and McFarland (1987: 298) 'pluralistic ignorance occurs when individuals infer that the identical actions of the self and others reflect different internal states. They propose that pluralistic ignorance arises most commonly in contexts where individuals believe that fear of embarrassment is a sufficient cause for their own behavior but not for the behavior of others and the term pluralistic ignorance usually refers to a gross systematic misperception of the actual distribution of opinions' (Millera and McFarland, 1987: 298 - as cited in Shamir, 1993: 23). Similarly, the false consensus effect as noted by Alicke and Edward (1995: 28), refers to the tendency to overestimate consensus for one's attitudes and behaviors. This overestimation may occur because people are biased in viewing their own positions as normative, or simply because they overgeneralize from case information, with their own positions representing one salient item of case information. Furthermore, as noted by Shamir (1992: 23) the looking-glass perception refers to people's tendency to attribute their own opinion to the majority. Looking-glass perception may result in erroneous estimates of the distribution of opinions just as inaccurate ones, depending on whether the perceiver is a member of the majority or the minority. Conservative bias refers to people's tendency to see others as more conservative than themselves when attributing opinions other than their own. The conservative bias phenomenon has not been accounted for theoretically, and some studies have also documented a 'liberal' or 'radical' bias in people's assessments (23). Similarly, the spiral of silence (SOS) theory developed by NoelleNeumann (1974) has been extensively used in the field of mass communication and public opinion research. As noted in Matthes, Morrison, and Schemer (2010: 775) SOS looks at the individuals who perceive their opinions to be in a majority position are more likely to express their views than those who feel that their opinions are not shared by most other people. The proposed reason for this process is a fear of social isolation, which leads the former group to speak out and the latter group to fall silent in spite of their actual distribution in a society. Likewise, the theory of third-person effect developed by W. Phillips Davison (1983) is also another aspect, which also influences the public opinions. As Perloff (1993: 167) notes:

Davison formulated the third-person effect hypothesis, a novel approach to the study of public opinion. Davison proposed that individuals typically assume that mass communications exert a stronger impact on others than the self, and he derived some interesting ideas from this notion. Over the past decade, a number of studies have tested predictions derived from Davison's formulation. ... A systematic review of third-person effect studies indicates that there is abundant support for the notion that individuals assume that communications exert a stronger influence on others than on the self. However, the third-person effect does not emerge in all circumstances and for all people. The effect appears to be particularly likely to emerge when the message contains recommendations that are not perceived to be personally beneficial, when individuals perceive that the issue is personally important, and when they perceive that the source harbors a negative bias. Considerably less is known about the processes that underlie the third-person effect.

The modern theory and framework (method) of public opinion survey is embodied through the historical account, classical theorists. The main objective to know the concern of the public is not altered. Governments, international organizations, non-profit organizations, business organizations, as well as scientific scholarly community as well as individuals are extensively using public opinion survey to find the views of the public on their interests. There are several methods in use to collect the public opinion; however, in recent years, the 
use of web based search and use of mass media has been growing exponentially (Bhandari, 2018). The mass emails with the questionnaire is a common tool for opinion collection. These opinion collectors have been drawing the results on the basis of the theoretical ground. However, there is always chances of pluralistic ignorance, false consensus, and the looking glass perception. These concern stakeholders (opinion collectors) utilize, 'these theories help to understand how perceived opinions differ from measured opinions as well as to assess the situations in which people believe that others' opinions are either more conservative or more liberal than their own. The third-person effect theory helps to explain public support for censorship and to analyze the misperception that a majority of other people are vulnerable to media messages. Similarly, the spiral of silence theory helps to understand that how society confirms or contrast and suggest for the change to the general perception as well as provide the alternative views and channels that fit within their circumstances' (World Bank- CommGAP, 2008: 4).

\section{Conclusion}

Theoretically and historically public opinion has been an important component in the state level to local level policy framing, planning to program implementation for the societal wellbeing. Mostly, the general public has been the core diver to run or function the society. However, historically, this notion was not documented or highlighted in chronological order. Noelle-Neumann (1991) nicely illustrates this dilemma as "It argues that public opinion did not appear first in the eighteenth century but has existed in all human societies for thousands of years as a force exerted on governments and individuals, creating and maintaining the consensus necessary for society's functioning. The word public in the concept of "public opinion" is to be interpreted in the sense of "public eye", "visible to all", and thus as social control. Opinion refers to publicly visible and audible expressions of opinion as well as public behavior regarding value-laden issues. Its power derives from our social nature, from the willingness of society to threaten isolation in reaction to forbidden opinions and behaviors, and from the individual's fear of isolation. This fear causes individuals to register continually any changes in society's approval by means of a "quasi-statistical sense", and to voice agreement upon increase in approval and to remain silent upon decrease, thus contributing to further decline in the popularity of the originally held opinion. The pressure of public opinion is a source of constant conflict for governments in weighing measures in order to win public support. Individuals also experience ongoing conflict between their individual inclinations and convictions and the social demands to conform" (Noelle-Neumann, 1991: 256).

It has been seen that the term survey and poll often used interchangeably, however they are different in their applicability. The public opinion survey mostly conducted by the government, academic institution or researchers to have certain ideas from the large population in some case through the entire population or from the clustered area. The surveyors use detail questionnaires, which may contain many questions and subquestions. Researchers may spend a long period of time to design survey question and series of follow-up questions. Surveyors may have face to face interviews with thousands of people or large population specific geographical area. In other words, the survey is mostly used to have public views or opinions on a specific topic or broad area. Normally the purpose of the survey is for the wellbeing of the general public. In the other hand, the poll normally is conducted with commercial purposes. Polls can be short, random and in yes or no questions. However, some larger firms, commercial organization may conduct extended polls to see their productivity and impact and use of their products and services (Traugott and Lavrakas 2000, IIA 2011) "the public sector consists of governments and all publicly controlled or publicly funded agencies, enterprises, and other entities that deliver public programs, goods, or services. A policy often comes in the form of general statements about priorities, written regulations or guidelines, procedures and/or standards to be achieved. At its simplest, policy refers to a distinct path of action which is suitable for the pursuit of desired goals within a particular context, directing the decision making of an organization or individual" (IIA 2011: 3).

As the propounding researcher of $20^{\text {th }}$ Century G. Gallup notes "When I speak of public opinion I refer to majority opinion, which must not be confused with noisy outbursts of minority groups and individuals who usually get headlines but seldom represent the collective judgment of the citizens of the country. Fortunately, today we have developed a technique and a machinery to sound the opinions of all the people of the nationboth those who shout and those who whisper" (Gallup G., 1941: 440); we should bear in mind that the public is a large segment of population, by which society formulate and whose voices make the difference in the communities at large. It does not mean that minority has no voice, however, the public opinion survey mostly voices of a larger segment of the population.

In sum-up, there is a long history of the public opinion survey, with a major objective to understand the people's true opinions/views on the issues of public concern. The use of opinion survey has exponential growth 
Business Ethics and Leadership, Volume 3, Issue 1, 2019

ISSN (online) - 2520-6311; ISSN (print) - 2520-6761

since the internet base date collection tool became major components of opinion collection (Bhandari, 2018). There are pros and cons in any survey tools; to minimize the errors effective tools and techniques are being utilized. However, still, the truth factor, reliability/validity of survey data depends on the sample size, education level of respondent, geographical location, culture of researcher and subject population. Still, there is a need for further research on the effectiveness of public opinion survey tools and techniques.

\section{Acknowledgments}

I would like to thank my wife and lifelong motivator, mentor Prajita Bhandari for her insightful comments, and inputs. I would also like to thank Manaslu, and Prameya especially for their support to me to concentrate on the paper as well as for their positive comments on the language pattern. Thanks to the editorial team, reviewers and readers as well.

\section{References}

1. Aaron, Richard (1937). John Locke, Oxford: Oxford University Press, Acta Sociologica, 39(4), 431-442.

2. Alicke, Mark D. and Edward, Largo (1995). The Role of Self in the False Consensus Effect. Journal of Experimental Social Psychology, 31(1), 28-47.

3. Allport, Floyd H. (1937). Toward a Science of Public Opinion. The Public Opinion Quarterly, 1(1), 7-23.

4. Allport, Gordon (1935). "Attitudes" in the Handbook of Psychology (edited by Carl Murchison, (Worcester, Mass) Clark University Press.

5. Avineri, Shlomo (1968). The Social and Political Thought of Karl Marx, Cambridge University Press.

6. Beniger, J. R. (1992). The impact of polling on public opinion: Reconciling Foucault, Habermas, and Bourdieu. International Journal of Public Opinion Research, 4, 204-219.

7. Bhandari, Medani P. (2018). Green Web-II: Standards and Perspectives from the IUCN, Published, sold and distributed by: River Publishers, Denmark/the Netherlands ISBN: 978-87-70220-12-5 (Hardback) 978-87-70220-11-8 (eBook).

8. Bhandari, Medani P. (2014). Civil Society and Non-Governmental Organizations (NGOs) Movements in Nepal and terms of Social Transformation. Pacific Journal of Science and Technology, 15(1), 177-189.

9. Blumer, H. (1969). Symbolic interactionism: Perspective and method. Berkeley: University of California Press. 10.Bromwich, D., and G. Kateb, eds. (2003). John Stuart Mill on Liberty, New Haven: Yale University Press.

11.Bryce, James (1921). Modern Democracies, 2 vols. London: Macmillan.

12.Callinicos, Alex (2010 [1983]). The Revolutionary Ideas of Karl Marx, Bloomsbury, London: Bookmarks.

13.Cassirer, Ernst (1945). Rousseau, Kant, Goethe, Princeton University Press.

14.Cheryl, Welch (2006). The Cambridge Companion to Tocqueville, Cambridge University Press.

15.Chicago Council on Global Affairs, \& WorldPublicOpinion.org (2007). Climate change and the global environment. Chicago: Chicago Council on Global Affairs.

16.Colman, John (1983). John Locke's Moral Philosophy, Edinburgh: Edinburgh University Press.

17.Crisp, Roger (1997). Mill on Utilitarianism (Routledge Philosophy Guidebook), London: Routledge.

18.Czaja, Ronald and Johnny Blair (1996). Designing Survey: A Guide to decisions and procedures, Thousands Oaks, Calif.: Pine Forge Press.

19.Damrosch, Leo (2005). Jean-Jacques Rousseau: Restless Genius. New York: Houghton Mifflin.

20.Davison, W. P. (1958). The public opinion process. Public Opinion Quarterly, 22, 91-106.

21.Davison, W. P. (1983). The third-person effect in communication. Public Opinion Quarterly, 47, 1-15.

22.Dewey, J. (1988 [1927]). The public and its problems. John Dewey: The later works, 1925-1953. Vol. 2, edited by J. Boydston, Carbondale: Southern Illinois University Press.

23.Dinwiddy, John (1989). Bentham, Oxford University Press.

24.Duncan, G. (1973). Marx and Mill: Two Views of Social Conflict and Social Harmony, Cambridge: Cambridge University Press.

25.ESOMAR/WAPOR (2014). Guideline on Opinion Polls and Published Surveys, World Research Codes and Guidelines, ESOMAR and WAPOR, USA/Netherlands.

26.Frankel, Martin R. and Frankel, Lester R. (1987). Fifty Years of Survey Sampling in the United States. The Public Opinion Quarterly, 51, Part 2: Supplement: 50th Anniversary Issue (1987), pp. 127-138.

27.Gallup, G. (1942). How Important Is Public Opinion in Time of War? Proceedings of the American Philosophical Society, 85(5), 440-444. Retrieved from http://www.jstor.org/stable/985063.

28.Gallup (2012). The Gallup Poll Public Opinion 2012, Edited by Frank Newport, Rowman \& Littlefield Publishers /Gallup Organization. http://media.gallup.com/muslimwestfacts/pdf/pollingandhowtouseitr1dreveng.pdf. 
Business Ethics and Leadership, Volume 3, Issue 1, 2019

ISSN (online) - 2520-6311; ISSN (print) - 2520-6761

29.Gallup (2007). Gallup's pulse of democracy: Environment. Retrieved 7 May 2017, from http://www.galluppoll.com/content/default.aspx?ci=1615\&pg=1.

30.Gilbert, Allan (1938). Machiavelli's Prince and Its Forerunners, Duke University Press.

31.GlobeScan (1999). Environics International Environmental Monitor Survey Dataset. Retrieved 14 April 2017, from http://jeff-lab.queensu.ca/poadata/analyze/iem/iem.shtml.

32.Goethe, Johann Wolfgang von (1970). Theory of Colors, translated by C.L. Eastlake, Boston: MIT Press.

33.Habermas, J. (1984). The theory of communicative action, Reason and the rationalization of society, Vol. 1, translated by T. McCarthy, 15-23, Boston: Beacon Press.

34.IIA (2011). Supplemental Guidance: Public Sector Definition, The Institute of internal Auditors, USA. https://na.theiia.org/standards-guidance/Public\%20Documents/Public\%20Sector\%20Definition.pdf .

35.Keller, Morton (1988). James Bryce and America. The Wilson Quarterly (1976-), 12(4), 86-95.

36.Kinnunen, Jussi (1996). Gabriel Tarde as a Founding Father of Innovation Diffusion Research. Acta Sociologica, 39(4), 431-442.

37.LaFreniere, Gilbert F. (1990). Rousseau and the European Roots of Environmentalism. Environmental History Review, 14(4), 41-72.

38.Latour, Bruno (2005). Reassembling the Social: An Introduction to Actor-Network-Theory, Oxford: Oxford University Press.

39.Macpherson, C. B. (1962). The Political Theory of Possessive Individualism: Hobbes to Locke. Oxford: Oxford University Press.

40.Mansfield, Harvey (1995). "Machiavelli and the Idea of Progress", in Melzer; Weinberger; Zinman, History and the Idea of Progress, Cornell University Press.

41. Matthes, Jörg; Morrison, Kimberly Rios and Schemer, Christian (2010). A Spiral of Silence for Some: Attitude Certainty and the Expression of Political Minority Opinions. Communication Research, 37(6) 774-800.

42.McLellan, David (2007). Marxism after Marx. Basingstoke: Palgrave Macmillan.

43.Millera, Dale T. and McFarland, Cathy (1987). Pluralistic Ignorance: When Similarity is interpreted as Dissimilarity (Interpersonal Relations and Group Processes). Journal of Personality and Social Psychology, 53(2), August 1987, pp. 298-305.

44.Murch, Arvin W. (1971). Public Concern for Environmental Pollution. The Public Opinion Quarterly, 35(1) (Spring, 1971), pp. 100-106.

45.Noelle-Neumann E. (1991). The Theory of Public Opinion: The Concept of the Spiral of Silence Annals of the International Communication Association, Volume 14, 1991 - Issue 1.

46.Noelle-Neumann, E. (1993). The spiral of silence: Public opinion-our social skin, 2nd ed. Chicago: University of Chicago Press.

47.Noelle-Neumann, E. (1995). Public opinion and rationality, In T. L. Glasser \& C. T. Salmon (Eds.), Public opinion and the communication of consent, 33-54, New York: Guilford Press.

48.Perloff, Richard M. (1993). Third-Person Effect Research 1983-1992: A Review and Synthesis. The International Journal of Public Opinion Research, 5(2), 167-184.

49.Pew Global Attitudes Project (2006). No global warming alarm in the U.S., China. Washington, D.C.: The Pew Research Center for the People \& the Press.

50.Pierson, George (1938). Tocqueville and Beaumont in America, Oxford University Press, New-York.

51.Robinson, Dave \& Groves, Judy (2003). Introducing Political Philosophy, Icon Books.

52.Roper Organization (1990). The Environment: Public Attitudes and Individual Behavior. New Ycrk: Roper Organization.

53.Rosen F. (1983). Jeremy Bentham and Representative Democracy: A Study of the "Constitutional Code", Oxford University Press.

54.Ross, L., Greene, D., \& House, P. (1977). The false consensus phenomenon: An attribution bias in selfperception and social psychological processes. Journal of Experimental Social Psychology, 13, $279-301$.

55.Schaefer, David (1990). The Political Philosophy of Montaigne, Cornell University Press.

56.Shamir, Jacob (1993). Pluralistic Ignorance Revisited: Perception of Opinion Distributions in Israel. The International Journal of Public Opinion Research, 5(1), 22-39.

57.Skinner, Quentin (1996). Reason and Rhetoric in the Philosophy of Hobbes's. Cambridge: Cambridge University Press.

58.Speier, Hans (1950). Historical Development of Public Opinion. The American Journal of Sociology, 55(4), 376-388.

59.Splichal, S. (1999). Public opinion: Developments and controversies in the Twentieth century, 221-269. Lanham, MD: Rowman \& Littlefield.

60.Strauss, Leo (1936). The Political Philosophy of Hobbes; Its Basis and Its Genesis. Oxford: Clarendon Press. 
61.Traugott, Michael W. and Paul J. Lavrakas (2000). The Voter's Guide to Election Polls, 2nd ed. New York: Chatham House.

62.Toews, David (2003). The New Tarde: Sociology after the End of the Social. Theory Culture \& Society, 20(5), 81-98.

63.Tuckness, Alex (2010). Retribution and Restitution in Locke's Theory of Punishment. Journal of Politics, 72, 720-732.

64.UNEP-UNFCC (1999). Adapted from IEA CO2 emissions from fuel combustion 1971-1998, Paris, 2000. See Climate Change Information Kit published by UNEP and UNFCCC, page 62.

65.World Bank- CommGAP (2008). World Bank - Communication for Governance \& Accountability Program (CommGAP), External Affairs Vice Presidency, The World Bank, Washington DC.

66.Wright, John F. S. (2001). Anglicizing the United States Constitution: James Bryce's Contribution to Australian Federalism, Publius: The Journal of Federalism, 31 (Winter 2001), 107-131.

67.Zunz, Oliver (edit. 2011). Alexis de Tocqueville and Gustave de Beaumont in America: Their Friendship and Their Travels (translated by Arthur Goldhammer), University of Virginia Press. 